\title{
Rekstur einkavæddra fyrirtækja á Íslandi
}

\author{
Pröstur Olaf Sigurjónsson og Auður Arna Arnardóttir ${ }^{1}$
}

\section{Ágrip}

Reglulega kemur upp umræða um pað hvort ríkið sé heppilegri eigandi fyrirtækja en einkaaðilar. Í kjölfar fjármálahrunsins haustið 2008 hefur slíka umræðu borið á góma. Spurningunni um hvort ríkið sé heppilegur eigandi verður ekki svarað nema með pví að leggja mat á árangur fyrri einkavæðingar. Pessi rannsókn greinir breytingar á rekstri íslenskra ríkisfyrirtækja sem einkavædd voru á árunum 1992-2005. Deildar meiningar eru um vinnubrögð í einkavæðingarferlinu sem viðhaft var á pessu tímabili og hefur einkavæðingu íslensku ríkisbankanna helst verið gerð skil. Sú rannsókn sem hér er birt greinir frá rekstri einkavæddu fyrirtækjanna, fyrir og eftir einkavæðingu, en ekki er gerð tilraun til pess að lýsa einkavæðingarferli peirra. Helstu niðurstöður eru pær að ekki er marktækur munur á rekstri fyrirtækjanna fyrir og eftir einkavæðingu. Reksturinn er skilvirkur bæði fyrir og eftir einkavæðingu. Samanburðarhópur einkafyrirtækja sýnir hins vegar marktækan bata í rekstri einkafyrirtækja í kjölfar einkavæðingar ríkisfyrirtækjanna.

\begin{abstract}
The question whether private or public ownership benefits society more, surfaces regularly. The financial collapse in the autumn of 2008 has re-vitalized the debate. Whether state ownership is more appropriate than private should be analyzed in the light of the outcome of prior privatizations. This paper analyzes changes in the operations of Icelandic privatized firms during the privatization period 1992-2005. The quality of the privatization process conducted during this period has been questioned, especially regarding the privatization of the Icelandic public banks. This paper does not concentrate on these processes but the changes in the operation of the privatized firms, based on analysis of 12 operational measures. The empirical research suggests that privatization did not lead to improvements of the divested SOEs in Iceland as their operations were equally efficient, even before privatization. Nevertheless, control groups of private firms perform better in the wake of the privatization.
\end{abstract}

JEL flokkun: G32

Lykilhugtök: Einkavæðing, afnám regluverks, rekstrarárangur.

\footnotetext{
${ }^{1}$ Höfundar starfa báðir sem lektorar við viðskiptadeild Háskólans í Reykjavík.
} 


\section{Inngangur}

Pessi rannsókn beinist að pví að greina breytingar í rekstri einkavæddra íslenskra fyrirtækja á árunum 1992-2005 út frá greiningu á kennitölum í rekstri. Viðfangsefnið er ekki að greina hvernig var staðið að einkavæðingu fyrirtækjanna, pað er áhugaverð síðari tíma rannsókn. Á tímabilinu 1992-2005 var einkavæðing ríkisfyrirtækja fyrirferðarmikil á Íslandi og voru flest ríkisfyrirtæki sem talin voru hæf til einkavæðingar einkavædd eða alls 33 fyrirtæki (Ríkisendurskoðun, 2003). Áhersla pessarar rannsóknar er á breytingar á rekstri fyrirtækjanna fyrir og eftir einkavæðingu og er samanburðarhópur einkafyrirtækja notaður í greiningunni. Höfundar vita ekki til pess að sambærileg greining á rekstri íslenskra einkavæddra fyrirtækja hafi verið gerð áður.

Erlendar rannsóknir á einkavæðingu eru margar og er niðurstaða peirra hvað árangur einkavæðingar varðar ekki einhlít. Meðal nýmarkaðslanda hefur breytingin á rekstri einkavæddra fyrirtækja yfirleitt verið ágæt pó að breytileikinn sé mikill, en meiri stöðugleiki og betri árangur hefur náðst meðal próaðra ríkja (Kikeri og Nellis, 2002). Norðurlöndin hafa próað með sér sterka laga- og stofnanaumgjörð sem er mikilvæg breyta hvað árangur einkavæðingar varðar (OECD, 2006). Norðurlöndin hafa jafnframt búið við skilvirkni í rekstri ríkisfyrirtækja (Willner, 2003) en pað kann að draga úr ávinningi einkavæðingar sé litið til rekstrar fyrirtækjanna.

Í pessari rannsókn er lagt upp með greiningu á rekstri einkavæddra fyrirtækja fyrir og eftir einkavæðingu. Pví er fyrri rannsóknarspurningin: Skiluðu einkavædd ríkisfyrirtæki betri árangri í rekstri eftir einkavæðingu? Jafnframt er gerð greining á peim mögulegu áhrifum sem einkavæðing kann að hafa á einkafyrirtæki í peim atvinnugreinum sem hún á sér stað. Pví er síðari rannsóknarspurningin: Hafði einkavæðing jákvæð áhrif á rekstur samanburðarhóps einkafyrirtækja?

Í næsta kafla er fjallað um rannsóknir á sviði einkavæðingar. Í kjölfarið er aðferðarfræði rannsóknarinnar lýst og peim gögnum sem stuðst er við. Í kafla fjögur eru niðurstöður kynntar og umræður er að finna í fimmta kafla.

\section{Rannsóknir á einkavæðingu}

Undanfarna tvo áratugi hefur einkavæðing verið talsvert rannsökuð, mest í Evrópu og nýmarkaðsríkjum Austur-Evrópu og Suður-Ameríku. Pessar rannsóknir gefa ágæta mynd af peim forsendum sem nauðsynlegar eru fyrir vel heppnaðri einkavæðingu. Kikeri og Nellis (2002) og Megginson (2003) gera meðal annarra góða grein fyrir forsendunum. Ef aðstæður á Íslandi eru speglaðar í niðurstöðum rannsókna erlendra fræðimanna hefði íslenska einkavæðingin getað heppnast ágætlega. Pólitísk samstaða ríkisstjórnarflokka fyrir einkavæðingu er nauðsynleg forsenda og má leiða að pví líkum að hún hafi verið fyrir hendi á Íslandi allt einkavæðingartímabilið 1992-2005. Sami stjórnmálaflokkurinn var burðarás ríkisstjórna pessa tímabils og sat sami forsætisráðherrann við völd mestallan tímann. Stuðningur almennings er önnur forsenda vel heppnaðrar einkavæðingar og var sá stuðningur meðal annars fenginn með umbun í formi skattaafsláttar vegna hlutabréfakaupa, par með talið hlutabréfa í nýeinkavæddum fyrirtækjum (Rannsóknarnefnd Alpingis, 2010). Almenningur varð með pessum hætti í sumum tilfellum stór eigandi einkavæddra fyrirtækja (Gylfi Magnusson, 2007). Önnur 
forsenda vel heppnaðrar einkavæðingar er að stjórnvöld tryggi samkeppni í einkavæddu atvinnugreinunum. Til pessa litu íslensk stjórnvöld, meðal annars við einkavæðingu fjármálafyrirtæka (Pröstur Olaf Sigurjónsson, 2010). Aukið frelsi í fjármálastarfsemi er talin mikilvæg forsenda í undanfara einkavæðingar fjármálafyrirtækja og skipti aðild Íslands að Evrópska efnahagssvæðinu árið 1993 miklu máli í pessu sambandi. Með samningnum tók Ísland upp flestar af reglum Evrópusambandsins og innleiddi stofnanaumgjörð pess. Afnám hafta skiptir árangur einkavæðingar jafnframt máli og segja má að einkavæðingarferlið á Íslandi hafi einkennst af „frelsisvæðingu“ allt frá árinu 1979 (Már Wolfgang Mixa og Pröstur Olaf Sigurjónsson, 2010). Hlutabréfamarkaður var settur á fót og efldur, svo og skuldabréfamarkaður til að auðvelda stofnanafjárfestum, svo sem lífeyrissjóðum, fjárfestingar. Gagnsæi í einkavæðingarferli er pekkt forsenda hvað árangur einkavæðingar varðar. Ríkisendurskoðun gaf reglulega út skýrslur um framgang einkavæðingarferlisins sem eftirlitsaðili en jafnframt í peim tilgangi að upplýsa um gang einkavæðingarinnar. Hins vegar er deilt er um hvort raunverulegt gagnsæi hafi ávallt verið til staðar (Rannsóknarnefnd Apingis, 2010).

Nokkrar greinar hafa komið út á undanförnum árum sem skapað hafa hefð í mælingum á breytingum á rekstri einkavæddra fyrirtækja (Boubakri og Cosset, 1998; D'Souza, Nash og Megginson, 2000; Megginson, Nash og Randeborgh, 1994; Megginson og Netter, 2001).

Gögnum um hefðbundnar kennitölur úr rekstri fyrirtækja er safnað í prjú ár fyrir og prjú ár eftir einkavæðingu. Árangur einkavæðingar hefur pannig fyrst og fremst verið metinn með mælingum á breytingum á rekstri einkavæddu fyrirtækjanna, með sambærilegum hætti og hefð hefur skapast um (Boubakri og Cosset, 1998; D'Souza, Nash og Megginson, 2000; Megginson, Nash og Randeborgh, 1994; Megginson og Netter, 2001).

Rannsakendum ber ekki saman um áhrif einkavæðingar. Rannsóknir sem sýna jákvæðar niðurstöður merkja pað með aukinni skilvirkni einkavæddu fyrirtækjanna, meiri hagnaði peirra og auknum fjárfestingum. Pessar rannsóknir ná bæði yfir iðnvædd vestræn ríki og vanpróuð ríki (Megginson og Netter, 2001; Bishop og Kay, 1988; Vining og Boardman, 1992). Choi og Silanes (2010) lengdu pann tíma sem skoðaður var og greindu gögn úr rekstri einkavæddra fyrirtækja tíu ár eftir einkavæðingu. Niðurstöðurnar voru pær að breytingar í rekstri ríkisfyrirtækjanna spegluðu eingöngu sveiflur í efnahagslífinu. Campbell og Bhatia (1998) sýndu í rannsókn sinni fram á að vanpróuð ríki höfðu fyrst og fremst hag af nýjum fjárfestingum einkavæddra fyrirtækja pegar ný tækni var innleidd og fjármálamarkaðir efldust. Boubakri og Cossett (1998) komust að svipaðri niðurstöðu en pó með peirri undantekningu að hagnaður, skilvirkni og framleiðsla jukust ekki marktækt. Ríkisfjármál batna hins vegar alls staðar við einkavæðingu af eðlilegum ástæðum (Davis, Ossowski, Richardson og Barnett, 2000). Styrkir til ríkisfyrirtækja stöðvast við einkavæðingu og fyrirtæki, sem vegnar vel eftir einkavæðingu, borga skatta (Sheshinski og Lopez-Calva, 1999). Almennt eru skattgreiðslur einkavæddra fyrirtækja hærri en arðgreiðslurnar sem pau greiddu fyrir einkavæðinguna (Kikeri og Nellis, 2002). Rannsakendur hafa jafnframt merkt aukin efnahagsleg umsvif í kjölfar einkavæðingar (Megginson og Choi, 2010). Hins vegar er sjaldgæft að allir hagsmunaaðilar, svo sem seljandi, kaupandi, viðskiptavinir, starfsmenn og samkeppnisaðilar, njóti ríkulegs ávinnings af einkavæðingu. Markmið einkavæðingar kunna að vera ólík bæði milli landa og milli fyrirtækja sem einkavædd eru. Ríkisvald getur ákveðið að selja ríkisfyrirtæki á lægra verði en hægt er að fá fyrir pað til að tryggja aðkomu margra aðila að kaupunum, að pau gangi hratt 
fyrir sig og að auknar líkur séu á að viðkomandi fyrirtæki standist samkeppni eftir eignarhaldsbreytinguna. Undir peim kringumstæðum hefur ríkisvaldið ákveðið að bera minna úr býtum við söluna sjálfa í ljósi væntinga um langtímaávinning fyrir pjóðarbúið (sjá til dæmis Megginson (2003) sem fjallar um ólíkar nálganir við einkavæðingu ríkisfyrirtækja).

\section{Gögn og aðferð}

\subsection{Gögn}

Úrtakið, sem stuðst er við í pessari rannsókn, samanstendur af öllum íslenskum einkavæddum fyrirtækjum á tímabilinu 1992-2005 par sem upplýsingar úr rekstri á priggja ára tímabilum eftir einkavæðingu eru fyrir hendi. Fyrirtækin eru úr ólíkum atvinnugreinum og af ólíkri stærð. Gagnagrunnurinn í pessari rannsókn er laus við pá skekkju sem er að finna í mörgum erlendum rannsóknum á einkavæðingu par sem aðeins er um stór fyrirtæki er að ræða annars vegar og hins vegar fyrirtæki sem hafa verið valin út frá skráningarhæfni á hlutabréfamarkað (Choi og Silanes, 2010). Gagnagrunnurinn verður jafnframt síður fyrir áhrifum valvillu par sem íslensk stjórnvöld einkavæddu ekki aðeins vænlegustu fyrirtækin heldur flest fyrirtæki sem mögulegt var að einkavæða (Kikeri og Nellis, 2002; Ríkisendurskoðun, 2003). Á meðan á einkavæðingartímabilinu 1992-2005 stóð einkavæddi íslenska ríkið alls 33 fyrirtæki (Már Wolfgang Mixa og Pröstur Olaf Sigurjónsson, 2010). Einkavæðingin fór að mestu fram með sölu hlutabréfa fyrirtækjanna. Í fjórum tilfellum voru eignir seldar en pað pýðir að viðkomandi fyrirtæki voru í kjölfarið afskráð. Рað eru pess vegna ekki til gögn um rekstur pessara fjögurra fyrirtækja eftir einkavæðingu. Tafla 1 veitir yfirlit yfir einkavæddu íslensku fyrirtækin, einkavæðingarárið og með hvaða hætti einkavætt var. Í peim tilfellum par sem upplýsingar úr rekstri lágu ekki opinberlega fyrir var haft samband við viðkomandi fyrirtæki. Pessi leið til gagnaöflunar átti við um flest fyrirtækin. Í peim tilfellum par sem fyrirtæki höfðu verið keypt eða pau sameinuð öðrum félögum strax eða fljótlega eftir einkavæðingu voru gögn ekki fyrir hendi. Einkavæðingartímabilið, sem rannsakað var, spannar tuttugu ár og í nokkrum tilfellum fundust gögn ekki prátt fyrir mikla eftirgrennslan. Í nokkrum tilfellum neituðu eigendur fyrirtækja að afhenda gögn til rannsóknarinnar. Prátt fyrir skyldu til að skila inn ársreikningum til Ríkisskattstjóra uppfylltu ekki öll fyrirtækin hana. Niðurstaðan er sú að upplýsingar um 20 einkavædd fyrirtæki eru notuð í rannsókninni.

Einkafyrirtæki úr ólíkum atvinnugreinum og af ólíkri stærð eru notuð sem samanburðarhópur í rannsókninni. ÍSAT 2008 atvinnugreinaskilgreiningin var notuð til pess að velja viðeigandi einkafyrirtæki til samanburðar við einkavætt fyrirtæki. ÍSAT 2008 atvinnugreinaskilgreiningin er byggð á NACE Rev. 2 atvinnugreinastaðli Evrópusambandsins. Listi yfir íslensk fyrirtæki með sömu atvinnugreinaskilgreiningu var fenginn frá Ríkisendurskoðun. Pau einkafyrirtæki sem höfðu sömu atvinnugreinaskilgreiningu, voru af svipaðri stærð og störfuðu á peim árum sem greining einkavæddu fyrirtækjanna nær yfir (prjú ár fyrir einkavæðingu og prjú ár eftir), voru valin til að vera í samanburðarhópnum. Sama regla gilti um gagnaöflun fyrir einkafyrirtækin og einkavæddu fyrirtækin. Par sem pað var mögulegt voru opinber gögn notuð. Par sem pað var ekki hægt var haft samband við fyrirtækin sjálf. Að endingu voru 29 einkafyrirtæki hæf til samanburðar. 
Tafla 1. Yfirlit yfir einkavædd fyrirtæki

Taflan sýnir einkavædd fyrirtæki 1992-2005, einkavæðingarár og tegund einkavæðingar.

\begin{tabular}{|c|c|c|c|}
\hline & Fyrirtæki & Lok einkavæðingar & Aðferð \\
\hline 1 & Flugskóli Íslands hf. & 2005 & Sala hlutabréfa \\
\hline 2 & Landssími Íslands hf. & 2005 & Blönduð aðferð \\
\hline 3 & Lánasjóður landbúnaðarins & 2005 & Sala hlutabréfa \\
\hline 4 & Barri hf. & 2004 & Sala hlutabréfa \\
\hline 5 & Búnaðarbanki Íslands hf. & 2003 & Blönduð aðferð \\
\hline 6 & Íslenskir aðalverktakar hf. & 2003 & Sala hlutabréfa \\
\hline 7 & Landsbanki Íslands hf. & 2003 & Blönduð aðferð \\
\hline 8 & Sementsverksmiðjan hf. & 2003 & Sala hlutabréfa \\
\hline 9 & Íslenska járnblendifélagið hf. & 2002 & Sala hlutabréfa \\
\hline 10 & Steinullarverksmiðjan hf. & 2002 & Sala hlutabréfa \\
\hline 11 & Kísiliðjan hf. & 2001 & Sala hlutabréfa \\
\hline 12 & Stofnfiskur & 2001 & Sala hlutabréfa \\
\hline 13 & Intís hf. & 2000 & Sala hlutabréfa \\
\hline 14 & Áburðarverksmiðjan hf. & 1999 & Sala hlutabréfa \\
\hline 15 & FBA & 1999 & Sala hlutabréfa \\
\hline 16 & Hólalax hf. & 1999 & Sala hlutabréfa \\
\hline 17 & Íslenska menntanetið hf. & 1999 & Sala hlutabréfa \\
\hline 18 & Skólavörubúð Námsgagnastofnunar & 1999 & Sala eigna \\
\hline 19 & Skýrr hf. & 1998 & Sala hlutabréfa \\
\hline 20 & Bifreiðaskoðun hf. & 1997 & Sala hlutabréfa \\
\hline 21 & Jarðboranir hf. & 1995 & Sala hlutabréfa \\
\hline 22 & Lyfjaverslun Íslands hf. & 1995 & Sala hlutabréfa \\
\hline 23 & Pörungaverksmiðjan hf. & 1995 & Sala hlutabréfa \\
\hline 24 & Pormóður rammi hf. & 1994 & Sala hlutabréfa \\
\hline 25 & Rýni hf. & 1993 & Sala hlutabréfa \\
\hline 26 & SR-mjöl hf. & 1993 & Sala hlutabréfa \\
\hline 27 & Ferðaskrifstofa Íslands hf. & 1992 & Bein sala til starfsfólks \\
\hline 28 & Framleiðsludeild ÁTVR & 1992 & Sala eigna \\
\hline 29 & Íslensk endurtrygging hf. & 1992 & Sala hlutabréfa \\
\hline 30 & Menningarsjóður & 1992 & Sala eigna \\
\hline 31 & Prentsmiðjan Gutenberg hf. & 1992 & Sala hlutabréfa \\
\hline 32 & Ríkisskip & 1992 & Sala eigna \\
\hline 33 & Próunarfélag Íslands hf. & 1992 & Sala hlutabréfa \\
\hline
\end{tabular}

Öll gögn voru leiðrétt með tilliti til verðbólgu par sem stuðst var við neysluverðsvísitölu pannig að einkavæðingarárið er grunnárið (ár 0). Rannsóknin styðst pví við gögn frá 20 einkavæddum fyrirtækjum og 29 einkafyrirtækjum, eða samtals 49 fyrirtækjum. 


\subsection{Aðferð}

Megginson, Nash og van Randerborgh (1994) lögðu til formlega aðferðarfræði við greiningu á breytingum í rekstri einkavæddra fyrirtækja og er hún nánast ráðandi nálgun í fræðunum. Peir lögðu til ákveðinn fjölda mælikvarða og samanburð miðgilda og meðaltals peirra mælikvarða prjú ár fyrir og prjú ár eftir einkavæðingu ríkisfyrirtækja (Choi og Silanes, 2010). Rannsóknin hér styðst við aðferð pessara höfunda og notar sex yfirflokka mælikvarða: (1) Arðsemi, (2) skilvirkni rekstrar, (3) afköst, (4) fjárfestingar, (5) skuldsetningu og (6) fjölda stöðugilda. Sjá töflu 2 yfir mælikvarða rannsóknarinnar.

Arðsemi er reiknuð með notkun priggja mælikvarða: Rekstrarhagnaður deilt með eignum (ROA), hagnaður ársins deilt með eigin fé (ROE) og rekstrarhagnaður deilt með sölu (ROS). Rekstrarhagnaður er notaður til pess að sýna árangur í rekstrinum sjálfum en hagnaður ársins er að teknu tilliti til breytinga á skuldsetningu sem fylgt getur einkavæðingu (Barber og Lyon, 1996). Til pess að greina breytingar á skilvirkni rekstrar eru prír mælikvarðar notaðir: Sala deilt með fjölda stöðugilda, hagnaður ársins deilt með fjölda stöðugilda og rekstrarhagnaður deilt með fjölda stöðugilda. Áhugavert er að nota mælikvarða sem taka til arðsemi rekstrar par sem ríkisfyrirtæki hafa stundum verið gagnrýnd fyrir slaka arðsemi (Frydman, Gray, Hessel og Rapaczynski, 2000; Kornai, 1998; Berglof og Roland, 1998).

Rannsóknir á einkavæðingu hafa margar sýnt marktæka aukningu á afköstum sem mæld

Tafla 2. Mælikvarðar á árangur í rekstri og spár um samband

Taflan sýnir pá mælikvarða sem notaðir eru til að leggja mat á breytingar á rekstri einkavæddra fyrirtækja í kjölfar einkavæðingar. Spár um breytingar eru sýndar í priðja dálki. Auðkennin $f$ og $e$ standa fyrir „fyrir einkavæðingu“ og „eftir einkavæðingu“. Öll tölugildi eru fengin úr ársreikningum viðkomandi reikningsárs.

\begin{tabular}{|c|c|c|}
\hline Mælikvarðar & Lýsing & Spár um samband \\
\hline \multicolumn{3}{|l|}{ Arðsemi } \\
\hline Arðsemi eigna (ROA) & Rekstrarhagnaður deilt með heildareignum & $\mathrm{ROA}_{\mathrm{e}}>\mathrm{ROA}_{\mathrm{f}}$ \\
\hline Arðsemi eigin fjár (ROE) & Hagnaður ársins deilt með eigið fé & $\mathrm{ROE}_{\mathrm{e}}>\mathrm{ROE}_{\mathrm{f}}$ \\
\hline Hagnaðarhlutfall (ROS) & Rekstrarhagnaður deilt með sölu & $\operatorname{ROS}_{\mathrm{e}}>\operatorname{ROS}_{\mathrm{f}}$ \\
\hline \multicolumn{3}{|l|}{ Skilvirkni } \\
\hline Sala/starfsfólk & Sala deilt með fjölda stöðugilda & $\begin{array}{l}\text { Sala/Starfsfólke> } \\
\text { Sala/Starfsfólkf }\end{array}$ \\
\hline OP/starfsfólk & Rekstrarhagnaður deilt með fjölda stöðugilda & $\mathrm{OP} / \mathrm{EMP}_{\mathrm{e}}>\mathrm{OP} / \mathrm{EMP}_{\mathrm{f}}$ \\
\hline NP/starfsfólk & Hagnaður ársins deilt með fjölda stöðugilda & NP/EMPe $>$ NP/EMPf \\
\hline \multicolumn{3}{|l|}{ Afköst/framleiðsla } \\
\hline Sala/heildareignir (Sala/HE) & Sala deilt með heildareignum & Sala/HEe $>$ Sala/HEf \\
\hline Sala & Samanburður á sölu milli tímabila & Salae $>$ Salaf \\
\hline \multicolumn{3}{|l|}{ Fjárfestingar } \\
\hline Fjárfest/sala & Aukning á fastafjármunum deilt með sölu & Fjárfe $>$ Fjárff \\
\hline Fjárfest/heildareignir & $\begin{array}{l}\text { Aukning á fastafjármunum deilt með } \\
\text { heildareignum }\end{array}$ & Fjárfe $>$ Fjárff \\
\hline \multicolumn{3}{|l|}{ Skuldsetning } \\
\hline Skuldsetning (skuld) & Skuldir deilt með eignum & Skuld $_{\mathrm{e}}<\mathrm{Skuld}_{\mathrm{f}}$ \\
\hline \multicolumn{3}{|l|}{ Starfsfólk } \\
\hline Starfsfólk & Fjöldi starfsfólks (stöðugildi) & Starfsfólke $<$ Starfsfólk \\
\hline
\end{tabular}


hefur verið með sölu og/eða framleiðslu, samfara einkavæðingu (Choi og Megginson, 2010). Í pessari rannsókn er breyting á afköstum mæld með tveimur kennitölum: Sölu deilt með heildareignum (veltuhlutfalli) og samanburði á sölu milli ára.

Áhrif einkavæðingar á fjárfestingar er greind með notkun mælikvarðanna: Fastafjármunir deilt með sölu, og fastafjármunir deilt með heildareignum. Раð skiptir máli að fylgjast með breytingum á pessum mælingum par sem sum ríkisfyrirtæki gegna mikilvægu hlutverki fyrir innviði samfélags og fjárfestingar pess skipta máli.

Rannsóknir sýna að skuldsetning fyrirtækja getur breyst í kjölfar einkavæðingar (Hansmann og Krakkman, 2000; Martin og Parker, 1997). Ríkisfyrirtæki njóta oft beinnar eða óbeinnar ríkisábyrgðar pannig að pau fjármagna sig ódýrar en einkafyrirtæki. Að auki er ekki hefðbundið að ríkisfyrirtæki gefi út hlutafé. Раð má pví reikna með að pau geti verið skuldsettari en einkafyrirtækin. Mælikvarði til að meta skuldsetningu í pessari rannsókn er hlutfall skulda af eignum.

Rannsóknum ber ekki saman um hvaða áhrif einkavæðing hefur á fjölda stöðugilda. Sumar rannsóknir sýna ekki aðeins fram á fækkun stöðugilda heldur jafnframt lækkun launa peirra sem eftir standa (sjá til dæmis rannsókn La Porta og Silanes, 1999). Aðrar rannsóknir sýna engar breytingar á pessu sviði (sjá til dæmis rannsókn Megginson, Nash og van Randerborgh, 1994). Í pessari rannsókn er fjöldi stöðugilda hvers fyrirtækis greindur fyrir og eftir einkavæðingu, mælt í fjölda stöðugilda.

Rannsóknin tekur tillit til almennra breytinga á efnahag á Íslandi yfir einkavæðingartímabilið með pví að nota samanburðarhóp einkafyrirtækja. Slík nálgun leiðréttir fyrir mögulegum sveiflum vegna breytinga á ýmsum ytri breytum, svo sem gengi gjaldmiðla, kaupmætti fólks og neyslumynstri og fleiri slíkum páttum. Pessir pættir ganga yfir öll fyrirtækin, hvort sem pau eru einkafyrirtæki eða ríkis-/einkavædd fyrirtæki, pó að vissulega geti verið munur á pví hversu sterk áhrifin eru á hvert og eitt peirra.

\section{Niðurstöður}

Niðurstöður breytinga á rekstri allra einkavæddu fyrirtækjanna 20 eru sýndar í töflu 3. Wilcoxon Signed Rank próf sýna að fimm af tólf mælikvörðum breytast marktækt eftir einkavæðingu. Ef litið er til arðsemi sýnir einn af premur mælikvörðum, ROE, tölfræðilega marktæka aukningu $(p<.10)$ eftir einkavæðingu. Aðrir arðsemismælikvarðar, hagnaður yfir sölu (ROS) og hagnaður yfir eignir (ROA), sýna ekki marktæka breytingu pó að ROS sýni bata í arðsemi fyrir $65 \%$ fyrirtækjanna.

Mælikvarðarnir prír sem notaðir eru til pess að mæla breytingar á skilvirkni rekstrar, pað er að segja sala deilt með fjölda stöðugilda, hagnaður ársins deilt með fjölda stöðugilda og rekstrarhagnaður deilt með fjölda stöðugilda, sýna allir tölfræðilega marktæka aukningu í skilvirkni rekstrar einkavæddra fyrirtækja eftir einkavæðingu. Auk pess sem 70 - 75\% allra fyrirtækjanna sýndu betri skilvirkni eftir einkavæðingu en fyrir $(p<.05)$. 
Tafla 3. Niðurstöður fyrir spár - öll einkavædd fyrirtæki

\begin{tabular}{|c|c|c|c|c|c|c|c|}
\hline Mælikvarðar & $N$ & $\begin{array}{l}\text { Meðaltal } \\
\text { fyrir } \\
\text { (miðgildi) }\end{array}$ & $\begin{array}{l}\text { Meðaltal } \\
\text { eftir } \\
\text { (miðgildi) }\end{array}$ & $\begin{array}{l}\text { Mismunur } \\
\text { meðaltals } \\
\text { (miðgildis) }\end{array}$ & $\begin{array}{l}\text { Z-próf fyrir } \\
\text { mismun } \\
\text { miðgildis }\end{array}$ & $\begin{array}{l}\text { Hlutfall fyrirtækja } \\
\text { sem breytist í pá } \\
\text { átt sem spád var } \\
\text { fyrir um }\end{array}$ & $\begin{array}{l}\text { P-gildi } \\
\text { fyrir } \\
\text { hlutfalls } \\
\text { prófun }\end{array}$ \\
\hline \multicolumn{8}{|l|}{ Arðsemi } \\
\hline ROA & 20 & $3,12(1,96)$ & $5,92(3,99)$ & $2,80(2,03)$ & $z=-0.971$ & 0.50 & 0.500 \\
\hline ROE & 20 & $4,22(5,77)$ & $7,67(8,96)$ & $3,45(3,19)$ & $z=-1.755^{*}$ & 0.70 & $0.037^{\text {** }}$ \\
\hline ROS & 20 & $-8,03(4,86)$ & $2,06(11,41)$ & $10,09(6,50)$ & $z=-0.859$ & 0.65 & $0.090^{*}$ \\
\hline \multicolumn{8}{|l|}{ Skilvirkni } \\
\hline Sala/starfsfólk & 20 & 13993(12004) & $25209(14004)$ & $11216(2000)$ & $z=-2427^{* *}$ & 0.75 & $0.013^{* *}$ \\
\hline NP/starfsfólk & 20 & $262(263)$ & $2272(992)$ & $2010(729)$ & $z=-1.755^{*}$ & 0.70 & $0.037^{\text {菏 }}$ \\
\hline OP/starfsfólk & 20 & $679(561)$ & $1702(1182)$ & $1023(621)$ & $z=-2.165^{*}$ & 0.75 & $0.013^{\text {** }}$ \\
\hline \multicolumn{8}{|l|}{ Framleiðsla } \\
\hline Sala/heildareignir & 20 & $0,838(0,705)$ & $0,981(0,847)$ & $0,144(0,142)$ & $z=-1.195$ & 0.60 & 0.190 \\
\hline Sala & 20 & $\begin{array}{l}4646165 \\
(811422)\end{array}$ & $\begin{array}{l}12629330 \\
(869008)\end{array}$ & $\begin{array}{l}7983165 \\
(5 / 586)\end{array}$ & $Z=-2.091^{* *}$ & 0.65 & $0.090^{*}$ \\
\hline \multicolumn{8}{|c|}{ Fjárfestingar í fastafjármunum } \\
\hline Fastafjármunir/sala & 20 & $0,71(2,04)$ & $9,50(3,50)$ & $8,78(1,46)$ & $z=-0.560$ & 0.55 & 0330 \\
\hline $\begin{array}{l}\text { Fastafjármunir/heildareignir } \\
\text { Skuldsetning }\end{array}$ & 20 & $1,844(0,689)$ & $-1,093(1,622)$ & $-2,937(0,932)$ & $z=-0.485$ & 0.50 & 0.500 \\
\hline Skuldir/eignir & 20 & $47,59(46,76)$ & $55,32(54,50)$ & $7,73(3,74)$ & $z=-1.008$ & 0.40 & 0814 \\
\hline \multicolumn{8}{|l|}{ Starfsfólk } \\
\hline EMP & 20 & $244(86)$ & $324(60)$ & $80(-26)$ & $z=-0.112$ & 0.45 & 0.673 \\
\hline
\end{tabular}

Niðurstöðurnar sýna marktæka aukningu í framleiðslu (afköstum) eftir að einkavæðing hefur átt sér stað $(p<.05)$. Pessi niðurstaða gengur gegn peirri algengu hugmynd að ríkisfyrirtæki framleiði umfram pað sem hagkvæmt er til pess að uppfylla pólitísk markmið og pví muni afköst dragast saman eftir einkavæðingu (Boycko, Shleifer og Vishny, 1994). Aukist afköst er hins vegar oft nefnd sú skýring að einkafyrirtæki hafi betri möguleika til fjármögnunar og sterkari hvata til meiri afkasta (Megginson, Nash og van Randenborgh, 1994). Mælikvarðinn, sala deilt með eignum, sýnir hins vegar ekki marktæka breytingu pó að 60\% fyrirtækjanna hreyfist í pá átt.

Hvorugur mælikvarðinn fyrir breytingar á fjárfestingum í fastafjármunum milli ára sýnir marktækar breytingar. En helmingur fyrirtækjanna hreyfist í pá átt sem spáð var, pað er að segja pau fjárfesta meira með hverju árinu. Pessi rannsókn styður pví ekki erlendar rannsóknir á einkavæðingu sem reikna með slíkri breytingu (Megginson, Nash og van Randenborgh, 1994).

Niðurstöðurnar gefa ekki til kynna breytingar á skuldsetningu fyrirtækja í kjölfar einkavæðingar. Pví var spáð að skuldsetning myndi lækka eftir einkavæðingu par sem einkafyrirtæki hafa ekki sama aðgang að ódýru lánsfé og ríkisfyrirtæki og ríkisfyrirtæki gefa ekki út hlutabréf. Hjá 60\% fyrirtækjanna aukast skuldir hins vegar. Rétt er að geta pess að ekki er um mörg fyrirtæki að ræða á tímabili mikillar almennrar skuldaaukningar 2003-2007.

Rannsókn pessi sýndi ekki fram á marktæka fækkun stöðugilda eftir einkavæðingu eins og rannsóknartilgáta gerði ráð fyrir. Alls fækkuðu 45\% fyrirtækja starfsfólki sínu eftir 
Tafla 4. Niðurstöður fyrir spár - öll einkavædd fyrirtæki nema fjármálafyrirtæki

\begin{tabular}{|c|c|c|c|c|c|c|c|}
\hline Mælikvarðar & $N$ & $\begin{array}{l}\text { Meðaltal } \\
\text { fyrir } \\
\text { (miðgildi) }\end{array}$ & $\begin{array}{l}\text { Meðaltal } \\
\text { eftir } \\
\text { (miðgildi) }\end{array}$ & $\begin{array}{l}\text { Mismunur } \\
\text { meðaltals } \\
\text { (miðgildis) }\end{array}$ & $\begin{array}{l}\text { Z-próf fyrir } \\
\text { mismun } \\
\text { miðgildis }\end{array}$ & $\begin{array}{l}\text { Hlutfall fyrirtækja } \\
\text { sem breytist í pá } \\
\text { átt sem spád var } \\
\text { fyrir um }\end{array}$ & $\begin{array}{l}\text { P-gildi } \\
\text { fyrir } \\
\text { hlutfalls } \\
\text { prófun }\end{array}$ \\
\hline \multicolumn{8}{|l|}{ Arðsemi } \\
\hline ROA & 18 & $3,40(3,91)$ & $6,51(6,72)$ & $3,11(281)$ & $z=-1.154$ & 0.50 & 0500 \\
\hline ROE & 18 & $4,00(4,2)$ & $7,40(8,96)$ & $3,40(4,74)$ & $z=-1502$ & 0.67 & $0.079^{4}$ \\
\hline ROS & 18 & $-9,97(3,95)$ & $-0,42(9,17)$ & $15,13(5,2)$ & $z=-0.415$ & 0.61 & 0.170 \\
\hline \multicolumn{8}{|l|}{ Skilvirkni } \\
\hline Sala/starfsfólk & 18 & 12419 (10816) & 22555 (12298) & 10135 (1482) & $z=-2069 * *$ & 0.72 & $0.030^{\text {s* }}$ \\
\hline NP/starfsfólk & 18 & 112 (176) & 717 (748) & $605(5 / 2)$ & $z=1.198$ & 0.67 & $0.0799^{*}$ \\
\hline OP/starfsfólk & 18 & $557(425)$ & $1279(887)$ & $721(462)$ & $z=1.677^{*}$ & 0.67 & $0.030^{\text {k* }}$ \\
\hline \multicolumn{8}{|l|}{ Framleiðsla } \\
\hline Sala/heildareignir & 18 & $0,92(0,78)$ & $1,08(0,89)$ & $0,16(0,11)$ & $z=1372$ & 0.67 & $0.079^{*}$ \\
\hline Sala & 18 & $\begin{array}{l}2361000 \\
(781267)\end{array}$ & $\begin{array}{l}2700600 \\
(764709)\end{array}$ & $\begin{array}{l}339600 \\
(-16558)\end{array}$ & $z=1590$ & 0.61 & 0.170 \\
\hline \multicolumn{8}{|l|}{ Fjárfestingar í fastafjármunum } \\
\hline Fastafjármunir/sala & 18 & $-0,11(1,11)$ & $1,41(-0,55)$ & $1,52(-1,66)$ & $z=0.152$ & 0.50 & 0500 \\
\hline $\begin{array}{l}\text { Fastafjármunir/heildareignir } \\
\text { Skuldsetning }\end{array}$ & 18 & $1,95(0,55)$ & $-1,70(-1,35)$ & $3,65(-1,90)$ & $z=0.762$ & 0.44 & 0.680 \\
\hline Skuldir/eignir & 18 & $42,44(43,78)$ & $51,38(51,99)$ & $8,94(8,21)$ & $z=-1.154$ & 0.33 & $0.092^{*}$ \\
\hline Starfsfólk & & & & & & & \\
\hline EMP & 18 & $172(74)$ & $144(52)$ & $-28(-22)$ & $z=0.719$ & 0.50 & 0.500 \\
\hline
\end{tabular}

einkavæðingu en 55\% peirra juku starfsmannafjölda eða stóðu í stað hvað fjölda starfsmanna áhrærir.

Pegar miðgildi og meðaltöl mælikvarðanna tólf eru borin saman kemur fram áhugaverður munur sem sést meðal annars á fjölda stöðugilda. Meðaltalið sýnir aukningu en miðgildið lækkun. Pegar hver atvinnugrein fyrir sig er skoðuð kemur í ljós að fjármálageirinn stendur upp úr hvað bata varðar pótt batinn hafi ekki verið sjálfbær eins og getið er í inngangi. Tafla 4 sýnir niðurstöðu tólf mælikvarða pessarar rannsóknar pegar tvö fyrirtæki í fjármálageiranum hafa verið tekinn út úr greiningunni. Niðurstaðan breytist frá pví að sýna marktækan mun fimm mælikvarða í pað að sýna aðeins í tveimur tilfellum marktækan mun ( $\mathrm{p}<.05)$. Pannig má vera ljóst að fjármálafyrirtækin hafa haft mikil áhrif pegar niðurstöður allra einkavæddra fyrirtækja eru greindar, par sem tölfræðilega marktækum batamerkjum fækkar verulega pegar peim er sleppt í greiningunni. Eftir standa einkavædd fyrirtæki sem sjaldnast sýna tölfræðilega marktækan jákvæðan viðsnúning. Rannsóknir á einkavæðingu hafa verið gagnrýndar fyrir að taka ekki tillit til breytinga á efnahagsumhverfi peirra efnahagssvæða sem til skoðunar eru (Choi og Silanes, 2010). Gagnrýnin beinist að pví að rannsóknir greini ekki á milli breytinga á rekstri fyrirtækjanna sem stafa annars vegar af breytingum á eignarhaldi og hins vegar breytingum á efnahagsumhverfi. Ísland naut hins vegar efnahagslegrar uppsveiflu á peim tíma sem hér er til skoðunar, 1992-2005, pótt hún hafi verið missterk eftir árum, lægð árið 1992 og aftur lægð árin 2001-2002. En til að styrkja rannsóknina enn frekar er samanburðarhópur einkafyrirtækja rannsakaður og veitir tafla 5 yfirlit yfir einkafyrirtækin. Einkafyrirtækin eru 
Tafla 5. Niðurstöður fyrir spár - öll einkafyrirtæki (samanburðarhópur)

Taflan sýnir niðurstöður fyrir öll einkafyrirtæki á tímabilinu 1992-2005 sem gögn voru til um. Fyrir hvern mælikvarða er meðaltal og miðgildi sýnt á priggja ára tímabilum eftir einkavæðingu. Mismunur gildanna er sýndur í dálki fimm. Sjötti dálkur sýnir niðurstöður Wilcoxon Signed Rank prófs á mismun miðgildanna. Síðustu tveir dálkarnir sýna hlutfall fyrirtækja sem breytast í pá átt sem spáð er og marktektarpróf á breytingu frá $50 \%, .01=* * *, .05=* *, o g .10=*$

\begin{tabular}{|c|c|c|c|c|c|c|c|}
\hline Mælikvarðar & $N$ & $\begin{array}{l}\text { Meðaltal } \\
\text { fyrir } \\
\text { (miðgildi) }\end{array}$ & $\begin{array}{l}\text { Meðaltal } \\
\text { eftir } \\
\text { (miðgildi) }\end{array}$ & $\begin{array}{l}\text { Mismunur } \\
\text { meðaltals } \\
\text { (miðgildis) }\end{array}$ & $\begin{array}{l}\text { Z-próf fyrir } \\
\text { mismun } \\
\text { miðgildis }\end{array}$ & $\begin{array}{l}\text { Hlutfall fyrirtækja } \\
\text { sem breytist í pá } \\
\text { átt sem spád var } \\
\text { fyrir um }\end{array}$ & $\begin{array}{l}\text { P-gildi } \\
\text { fyrir } \\
\text { hlutfalls } \\
\text { prófun }\end{array}$ \\
\hline \multicolumn{8}{|l|}{ Arðsemi } \\
\hline ROA & 29 & $6,83(5,43)$ & $6,44(1,22)$ & $-0,39(-0,42)$ & $z=-0.205$ & 0.48 & 0.570 \\
\hline ROE & 29 & $5,32(5,65)$ & $4,65(4,98)$ & $-0,66(-0,68)$ & $z=-0.811$ & 0.45 & 0.710 \\
\hline ROS & 29 & $5,49(10,32)$ & $24,65(24,24)$ & $19,17(13,93)$ & $z=-3.0 B^{* *}$ & 0.69 & $0.021^{\text {** }}$ \\
\hline \multicolumn{8}{|l|}{ Skilvirkni } \\
\hline Sala/starfsfólk & 29 & 21439 (24225) & 21949 (19566) & $510(-4659)$ & $z=-0.097$ & 0.52 & 0.436 \\
\hline NP/starfsfólk & 29 & 1578 (1004) & 4924 (1746) & $3345(743)$ & $z=-3276^{* *}$ & 0.72 & $0.008^{\text {s*t* }}$ \\
\hline OP/starfsfólk & 29 & 876 (726) & $896(788)$ & $20(62)$ & $Z=-0.443$ & 0.48 & 0.574 \\
\hline \multicolumn{8}{|l|}{ Framleiðsla } \\
\hline Sala/heildareignir & 29 & $0,95(0,80)$ & $0,79(0,69)$ & $-0,16(-0,11)$ & $z=-2.952 *$ & 021 & 0.999 \\
\hline Sala & 29 & $\begin{array}{l}2646694 \\
(1272771)\end{array}$ & $\begin{array}{l}4777186 \\
(1437 / 57)\end{array}$ & $\begin{array}{l}2130491 \\
(164986)\end{array}$ & $Z=-3319^{\text {*** }}$ & 0.72 & $0.008^{\text {s*x* }}$ \\
\hline \multicolumn{8}{|l|}{ Fjárfestingar í fastafjármunum } \\
\hline Fastafjármunir/sala & 29 & $-0,45(2,65)$ & $13,07(10,71)$ & $13,52(8,05)$ & $Z=-2887^{* *}$ & 0.76 & $0.003^{* * * *}$ \\
\hline $\begin{array}{l}\text { Fastafjármunir/heildareignir } \\
\text { Skuldsetning }\end{array}$ & \multicolumn{6}{|c|}{ Skuldsetning } & $0.003^{* * * *}$ \\
\hline Skuldir/eignir & 29 & $72,04(82,13)$ & $64,79(81,84)$ & $-7,25(-0,29)$ & $z=-2519^{* * *}$ & 0.72 & $0.008^{* * * *}$ \\
\hline \multicolumn{8}{|l|}{ Starfsfólk } \\
\hline EMP & 29 & $128(62)$ & $165(72)$ & $37(10)$ & $Z=-3.473^{\text {** }}$ & 021 & 0.999 \\
\hline
\end{tabular}

„tvífarar“ einkavæddu fyrirtækjanna par sem pau hafa sömu skilgreiningar í atvinnugreinaskrá (sjá kafla prjú um gögnin og aðferðarfræðina) og hvert tímabil er pað sama fyrir hvert „par“ (sömu ár fyrir einkavæðingu og sömu ár eftir einkavæðingu fyrir bæði einkavætt fyrirtæki og einkafyrirtæki).

Pegar niðurstöður fyrir samanburðarhópinn eru greindar kemur í ljós marktækur munur á átta af tólf mælikvörðum (sjá töflu 5). Marktækan mun er að finna á mörgum mælikvörðum par sem einkavæddu fyrirtækin sýndu engan marktækan mun eins og í fjárfestingum, skuldsetningu og fjölda starfsfólks. Samanburðarhópurinn sýnir marktæka aukningu í fjölda starfsfólks, lækkun skuldsetningar og aukningu í fastafjármunum. Á hinn bóginn sýna einkafyrirtækin bata í skilvirkni rekstrar í aðeins einum af premur mælikvörðum og marktækur bati í arðsemi sést aðeins í einum af premur mælikvörðum. Pegar fjármálafyrirtæki eru tekin úr greiningunni birtist marktækur munur sjaldnar (sjá töflu 6). Fjöldi marktækra breytinga fer úr átta í fimm. Einkafyrirtækin sýna enn marktæka breytingu í einum af mælikvörðunum til að meta arðsemi (ROS), í báðum mælikvörðum fyrir afköst, fyrir skuldsetningu og fyrir breytingu á fjölda starfsfólks.

Eftir einkavæðingu eykst arðsemin tölfræðilega marktækt eins og myndir 1 til 3 gefa til kynna. pær sýna hvað gerist yfir tíma hvað einstaka mælikvarða varðar, bæði fyrir einkavæddu fyrirtækin og einkafyrirtækin. Arðsemi eigin fjár (ROE) ríkisfyrirtækjanna er helmingi lægri en einkafyrirtækjanna fyrir einkavæðingu en er svipuð eftir einkavæðingu par sem einkafyrirtæki standa mikið í stað meðan einkavæddu fyrirtækin sýna bata. Arðsemi eigna (ROA) er lakari hjá 
Tafla 6. Niðurstöður fyrir spár - öll einkafyrirtæki að fjármálafyrirtækjum undanskyldum Taflan sýnir niðurstöður fyrir öll einkafyrirtæki á tímabilinu 1992-2005 sem gögn voru til um. Fyrir hvern mælikvarða er meðaltal og miðgildi sýnt á priggja ára tímabilum eftir einkavæðingu. Mismunur gildanna er sýndur í dálki fimm. Sjötti dálkur sýnir niðurstöður Wilcoxon Signed Rank prófs á mismun miðgildanna. Síðustu tveir dálkarnir sýna hlutfall fyrirtækja sem breytast í pá átt sem spáð er og marktektarpróf á breytingu frá $50 \%, .01=* * * .05=* *, \operatorname{og} .10=*$

\begin{tabular}{|c|c|c|c|c|c|c|c|}
\hline Mælikvarðar & $N$ & $\begin{array}{l}\text { Meðaltal } \\
\text { fyrir } \\
\text { (miðgildi) }\end{array}$ & $\begin{array}{l}\text { Meðaltal } \\
\text { eftir } \\
\text { (miðgildi) }\end{array}$ & $\begin{array}{l}\text { Mismunur } \\
\text { meðaltals } \\
\text { (miðgildis) }\end{array}$ & $\begin{array}{l}\text { Z-próf fyrir } \\
\text { mismun } \\
\text { miðgildis }\end{array}$ & $\begin{array}{l}\text { Hlutfall fyrirtækja } \\
\text { sem breytist í pá } \\
\text { átt sem spád var } \\
\text { fyrir um }\end{array}$ & $\begin{array}{l}\text { P-gildi } \\
\text { fyrir } \\
\text { hlutfalls } \\
\text { prófun }\end{array}$ \\
\hline \multicolumn{8}{|l|}{ Arðsemi } \\
\hline ROA & 18 & $11,15(9,16)$ & $10,55(10,95)$ & $-0,60(1,79)$ & $z=-0.109$ & 056 & 0319 \\
\hline ROE & 18 & $9,46(9,21)$ & $8,77(10,12)$ & $-0,69(0,91)$ & $z=-0370$ & 050 & 0500 \\
\hline ROS & 18 & $7,03(11,03)$ & $25,98(26,21)$ & $18,95(15,18)$ & $z=-2069^{* *}$ & 0.61 & 0.173 \\
\hline \multicolumn{8}{|l|}{ Skilvirkni } \\
\hline Sala/starfsfólk & 18 & $15689(12977)$ & 14784 (11612) & $-905(-1365)$ & $z=0.457$ & 050 & 0500 \\
\hline NP/starfsfólk & 18 & $784(383)$ & $1507(804)$ & $723(421)$ & $z=1590$ & 0.61 & 0.173 \\
\hline OP/starfsfólk & 18 & $1401(733)$ & $1436(1151)$ & $35(418)$ & $Z=0.457$ & 056 & 0389 \\
\hline \multicolumn{8}{|l|}{ Framleiðsla } \\
\hline Sala/heildareignir & 18 & $1.45(3.25)$ & $121(0.99)$ & $-0.24(-226)$ & $z=2504^{* *}$ & 028 & 0970 \\
\hline Sala & 18 & $\begin{array}{l}1443826 \\
(1297 / 38)\end{array}$ & $\begin{array}{l}2004309 \\
(1356869)\end{array}$ & $\begin{array}{l}560483 \\
\text { (59131) }\end{array}$ & $z=2417^{\text {** }}$ & 0.72 & $0.030^{\text {s* }}$ \\
\hline \multicolumn{8}{|l|}{ Fjárfestingar í fastafjármunum } \\
\hline Fastafjármunir/sala & 18 & $2,16(2,94)$ & $4,41(3,64)$ & $2,25(0,70)$ & $z=0.675$ & 0.61 & 0.173 \\
\hline Fastafjármunir/heildareignir & 18 & $-3,21(2,99)$ & $4,60(6,2)$ & $7,81(3,23)$ & $z=1.032$ & 0.68 & $0.079^{*}$ \\
\hline \multicolumn{8}{|l|}{ Skuldsetning } \\
\hline Skuldir/eignir & 18 & 60.67 (59.95) & $5202(54.59)$ & $-8.65(-536)$ & $z=-1.807^{*}$ & 0.72 & $0.030^{\text {t* }}$ \\
\hline \multicolumn{8}{|l|}{ Starfsfólk } \\
\hline EMP & 18 & $125(73)$ & $158(129)$ & $33(56)$ & $z=2983^{* *}$ & 0.78 & $0.009^{m * * *}$ \\
\hline
\end{tabular}

einkafyrirtækjunum fyrir einkavæðingu en batnar verulega eftir einkavæðingu. Pað er aðeins á mælikvarðanum arðsemi sölu (ROS) sem einkavædd fyrirtæki ná ekki sama árangri og einkafyrirtækin pó að pau bæti sig.

Mælikvörðum fyrir skilvirkni er með sama hætti lýst á myndum 4 og 5 (með sölu yfir fjölda starfsfólks og hagnaði yfir fjölda starfsfólks). Skilvirkni batnar eftir einkavæðingu og styður pað kenningar um að einkavæðing ríkisfyrirtækja leiði til aukinnar skilvirkni. Í pessu sambandi má líta til rannsókna Martin og Parker (1997) og einnig Dewenter og Malatesta (2001) sem sýna pessa niðurstöðu. Allir mælikvarðarnir til að meta skilvirkni í rekstri sýna marktækan bata.

Á hinn bóginn fækkar starfsfólki ríkisfyrirtækjanna talsvert en pó mest árin fyrir einkavæðingu (árin -3 til 0). Á móti kemur að einkafyrirtækin auka við fjölda starfsfólks fyrir samanburðartímabilin. Pessar niðurstöður gefa til kynna að fækkun starfsfólks er hluti af aukinni skilvirkni ríkisfyrirtækja eftir einkavæðingu (sjá mynd 6).

Pegar niðurstöðurnar eru metnar með báða hópa fyrirtækja í huga, að undanskyldum fjármálafyrirtækjum ( $\mathrm{N}=18$ fyrir einkavædd fyrirtæki og $\mathrm{N}=18$ fyrir einkafyrirtæki), er ljóst að einkavæddu fyrirtækin sýna varla marktækar breytingar (aðeins samkvæmt tveimur af tólf mælikvörðum) en einkafyrirtækin sýna marktækan bata samkvæmt fimm af tólf mælikvörðum. Einkavæddu fyrirtækin sýna marktækan mun í mælikvörðunum fyrir skilvirkni en einkafyrirtækin samkvæmt fleiri tegundum mælikvarða eða arðsemi, framleiðslu, skuldsetningu og fjölda stöðugilda. Hins vegar er tilhneiging í báðum flokkum fyrirtækja til að 


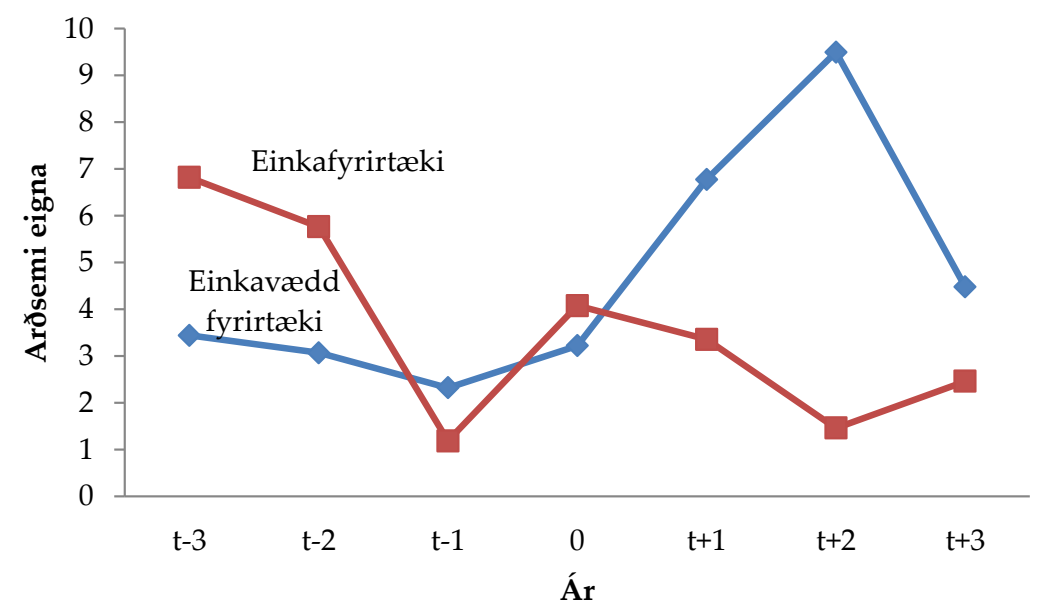

Mynd 1. Arðsemi eigna einkavæddra fyrirtækja og einkafyrirtækja

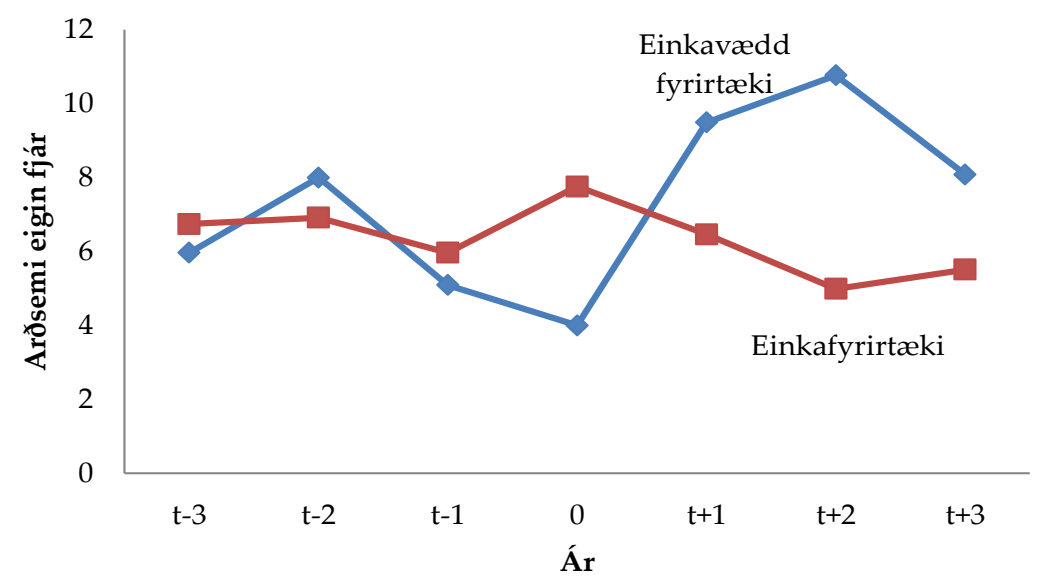

Mynd 2. Arðsemi eigin fjár einkavæddra fyrirtækja og einkafyrirtækja

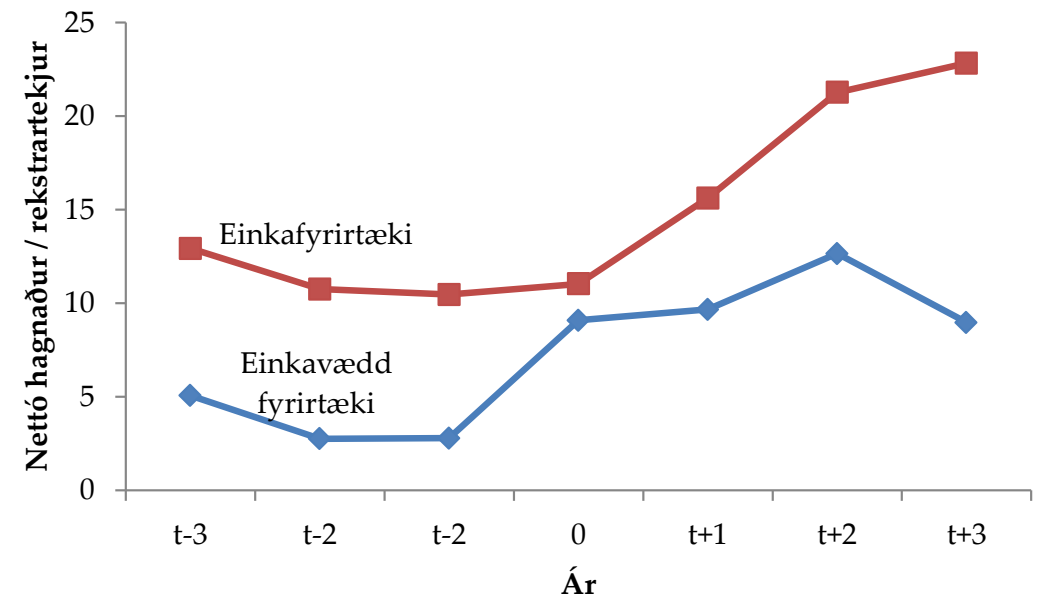

Mynd 3. Arðsemi sölu einkavæddra fyrirtækja og einkafyrirtækja 


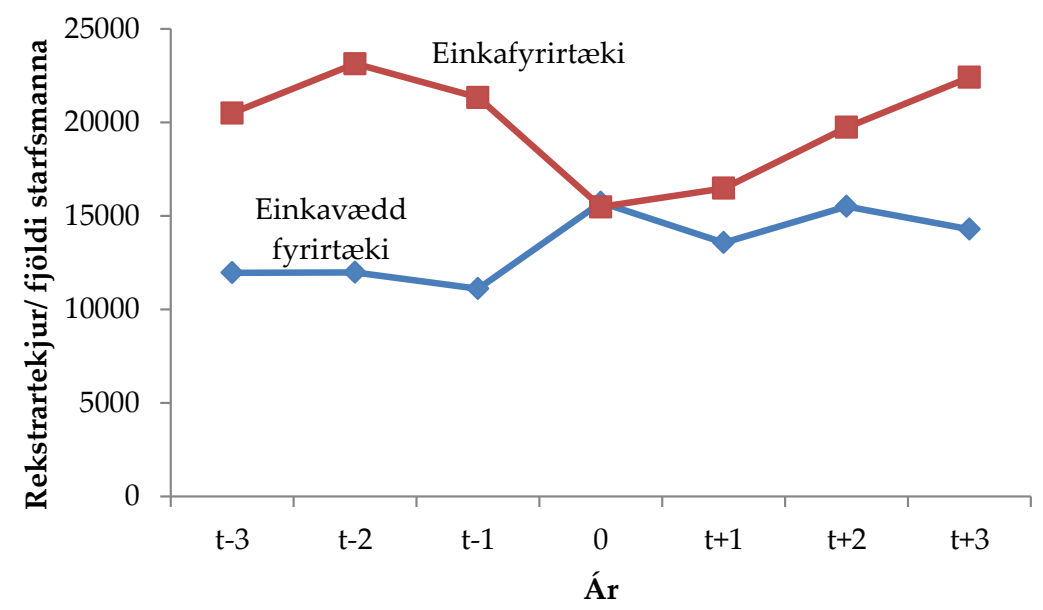

Mynd 4. Hlutfall (miðgildi) sala yfir fjölda starfsmanna einkavæddra fyrirtækja og einkafyrirtækja

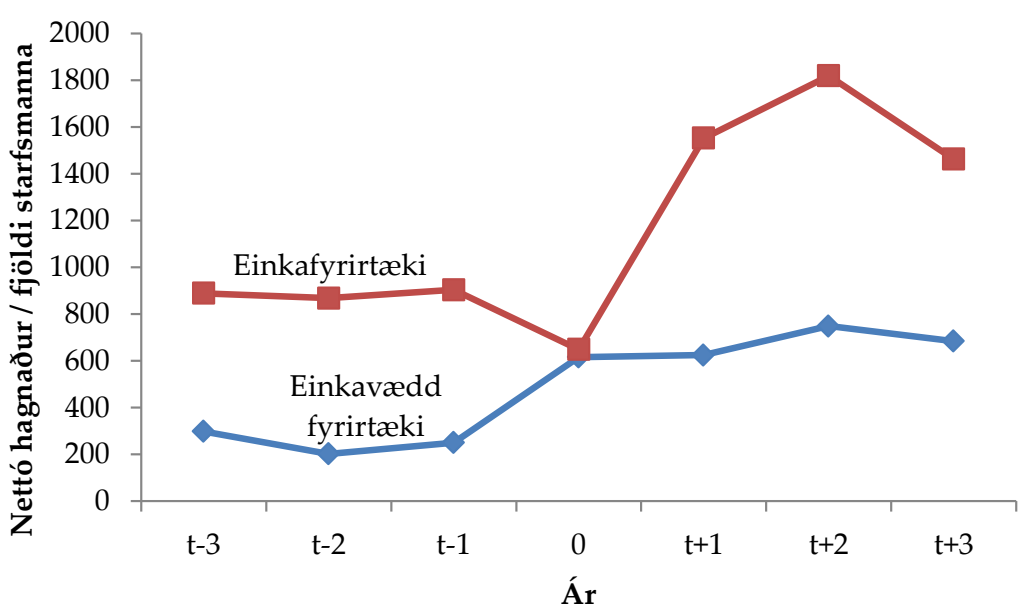

Mynd 5. Hlutfall (miðgildi) hagnaðar ársins yfir fjölda starfsmanna fyrir einkavædd fyrirtæki og einkafyrirtæki

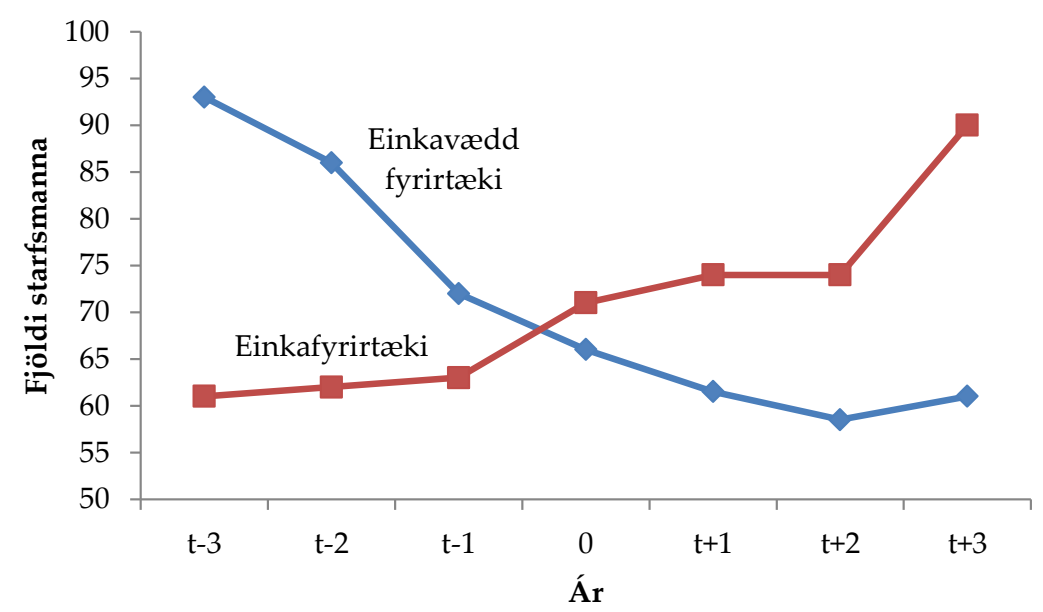

Mynd 6. Fjöldi starfsmanna einkavæddra fyrirtækja og einkafyrirtækja 
hreyfast í pá átt sem spáð var. Chi-kvaðrat prófi var beitt til að bera saman hvort annar hópurinn, einkafyrirtæki eða einkavædd, væri marktækt ólíkur hinum samkvæmt hinum tólf mælibreytum (sjá töflu 7). Prófanir leiddu í ljós marktækan mun á einungis premur breytum, framleiðslu (sala/heildareignir), skuldsetningu og fjölda starfsfólks. Einkafyrirtækin eru 5,3 sinnum líklegri til pess að færast í átt til pess að lækka skuldsetningu sína og 3,6 sinnum líklegri til pess að fjölga starfsfólki. Á hinn bóginn eru einkavæddu fyrirtækin 5,3 sinnum líklegri til pess að auka mælikvarðann sala yfir heildareignum. Раð er ekki marktækur munur milli hópanna hvað aðrar kennitölur varðar.

\section{Umræða}

Niðurstöðurnar sýna að íslensku ríkisfyrirtækin voru arðsöm fyrir einkavæðingu og halda áfram að vera pað eftir breytingu á eignarhaldinu. Prátt fyrir að lítið sé um tölfræðilega marktækar breytingar á rekstri peirra, er tilhneigingin í átt til betri rekstrar. Tölfræðilega marktækar breytingar er aðeins að finna í tveimur mælikvörðum af tólf (pegar fjármálafyrirtækin hafa verið undanskilin). Pær breytingar virðast mega rekja til fækkunar stöðugilda einkavæddu fyrirtækjanna, sérstaklega í aðdraganda einkavæðingarinnar. Pess ber pó að geta að prátt fyrir að höfundar hafi safnað gögnum yfir einkavæðingu á Íslandi frá 1992 til 2005, pá er fjöldi einkavæddra fyrirtækja í rannsókninni ekki mikill sem haft getur áhrif á niðurstöður útreikninga hvað marktækni varðar. Hins vegar eru í rannsókninni langflest peirra einkavæddu íslensku fyrirtækja sem tölulegum böndum verður komið yfir, úr öllum atvinnugreinum og hvort sem um er að ræða stór eða smá fyrirtæki. Slíkt úrtak er pví á margan hátt frábrugðið einsleitari úrtökum erlendra rannsókna á einkavæðingu (Boubakri og Cosset, 1998; D’Souza, Nash og Megginson, 2000; Megginson, Nash og Randeborgh, 1994; Megginson og Netter, 2001).

Samanburðarhópur einkafyrirtækja á tímabilinu 1992-2005 er notaður til pess að leiðrétta fyrir mögulegum sveiflum í íslensku efnahagslífi. Báðir hópar fyrirtækja sýna svipaða próun en einkafyrirtækin sýna pó marktækar breytingar samkvæmt fleiri mælikvörðum. Рað virðist ýta við peim að standa andspænis breyttri samkeppni, pað er að segja einkavæðingunni, burt séð frá ástandi efnahagsmála á hverjum tíma. Fækkun starfsfólks einkavæddu fyrirtækjanna virðist vera ráđandi páttur í breytingum á skilvirkni peirra. Petta gefur til kynna að einkavæðingin leiði ekki til marktæks bata nema fyrir fækkun starfsfólks. Á hinn bóginn undirbúa einkafyrirtæki sig gagnvart breyttu samkeppnisumhverfi með pví að leita eftir aukinni arðsemi og skilvirkni. Pau bæta sig á flestum mælikvörðum, pó ekki í peim sem mæla skilvirkni en pað er líklega vegna pess að einkafyrirtækin fjölga starfsfólki í kjölfar einkavæðingar. Pess ber pó að geta að einkafyrirtækin voru arðsöm og skilvirk fyrir einkavæðingu.

Áhrif einkavæðingar á ríkisfjármál eru jákvæð en á pessu tímabili lækkuðu opinberar skuldir sem hlutfall af landsframleiðslu úr 33,7\% í 7,4\%. Tilkynningar um fyrirhugaða einkavæðingu ríkisfyrirtækis virðast strax hafa mikil áhrif. Fækkun stöðugilda ríkisfyrirtækja á árunum fyrir einkavæðingu (eftir að tilkynnt hefur verið um fyrirhugaða einkavæðingu) er talsverð, eða 40\%. Hins vegar tekur tíma að láta breytingarnar skila sér í árangri í rekstri. 
Tafla 7. Niðurstöður Pearson Chi-kvaðrat prófs fyrir hópa einkavæddra fyrirtækja og einkafyrirtækja

Prófið kannar hvort pað séu tengsl milli hópanna tveggja (einkavæddra fyrirtækja og einkafyrirtækja) og hvort peir taka spáðum breytingum eða ekki í kjölfar einkavæðingar. Fjármálafyrirtæki eru undanskilin í báðum hópum fyrirtækja ( $\mathrm{N}=18$

\begin{tabular}{|c|c|c|c|c|c|c|}
\hline & $\begin{array}{l}\text { Tegund } \\
\text { fyrirtækis }\end{array}$ & $N$ & $\begin{array}{l}\text { Fjöldi sem } \\
\text { tekur spáðum } \\
\text { breytingum }\end{array}$ & $\begin{array}{l}\text { Fjöldi sem tekur } \\
\text { ekki spádum } \\
\text { breytingum }\end{array}$ & Ki-kvaðrat & Hlutfall \\
\hline \multicolumn{7}{|l|}{ Arðsemi } \\
\hline \multirow[t]{2}{*}{ ROA } & Einkavædd & 18 & 9 & 9 & $X^{2}(1, N=36)=0.110$ & 0.8 \\
\hline & Einka & 18 & 10 & 8 & & \\
\hline \multirow[t]{2}{*}{ ROE } & Einkavædd & 18 & 12 & 6 & $X^{2}(1, N=36)=1.029$ & 20 \\
\hline & Einka & 18 & 9 & 9 & & \\
\hline \multirow[t]{2}{*}{ ROS } & Einkavædd & 18 & 11 & 7 & $X^{2}(1, N=36)=0.000$ & 1.00 \\
\hline & Einka & 18 & 11 & 7 & & \\
\hline \multicolumn{7}{|l|}{ Skilvirkni } \\
\hline \multirow[t]{2}{*}{ Sales/EMP } & Einkavædd & 18 & 13 & 5 & $X^{2}(1, N=36)=1.870$ & 26 \\
\hline & Einka & 18 & 9 & 9 & & \\
\hline \multirow[t]{2}{*}{ NP/EMP } & Einkavædd & 18 & 12 & 6 & $X^{2}(1, N=36)=0.120$ & 127 \\
\hline & Einka & 18 & 11 & 7 & & \\
\hline \multirow[t]{2}{*}{ OP/EMP } & Einkavædd & 18 & 12 & 6 & $X^{2}(1, N=36)=0.468$ & 1.6 \\
\hline & Einka & 18 & 10 & 8 & & \\
\hline \multicolumn{7}{|l|}{ Framleiðsla } \\
\hline \multirow[t]{2}{*}{ Sala/heildareignir } & Einkavædd & 18 & 12 & 6 & $X^{2}(1, N=36)=5.466^{* *}$ & 526 \\
\hline & Einka & 18 & 5 & 13 & & \\
\hline \multirow[t]{2}{*}{ Sala/heildareignir } & Einkavædd & 18 & 11 & 7 & $X^{2}(1, N=36)=0.500$ & 0.6 \\
\hline & Einka & 18 & 13 & 5 & & \\
\hline \multicolumn{7}{|l|}{$\begin{array}{l}\text { Fjárfestingar í } \\
\text { fastafjármunum }\end{array}$} \\
\hline \multirow[t]{2}{*}{ Fastafjármunir/sala } & Einkavædd & 18 & 9 & 9 & $X^{2}(1, N=36)=0.50$ & 0.64 \\
\hline & Einka & 18 & 11 & 7 & & \\
\hline \multirow[t]{2}{*}{ Fastafjármunir/sala } & Einkavædd & 18 & 8 & 10 & $X^{2}(1, N=36)=1.800$ & 0.4 \\
\hline & Einka & 18 & 12 & 6 & & \\
\hline \multicolumn{7}{|l|}{ Skuldsetning } \\
\hline \multirow[t]{2}{*}{ Skuldir/eignir } & Einkavædd & 18 & 6 & 12 & $X^{2}(1, N=36)=5.461^{* *}$ & 0.19 \\
\hline & Einka & 18 & 13 & 5 & & \\
\hline \multicolumn{7}{|l|}{ Starfsfólk } \\
\hline \multirow[t]{2}{*}{ Starfsfólk } & Einkavædd & 18 & 9 & 9 & $X^{2}(1, N=36)=3.010^{*}$ & 028 \\
\hline & Einka & 18 & 14 & 4 & & \\
\hline
\end{tabular}

Í rannsókninni er peirri spurningu varpað fram hvort einkavæðing íslenskra ríkisfyrirtækja skili marktækum bata fyrir rekstur peirra. Stutta svarið er nei. Rekstur peirra breytist hins vegar í jákvæða átt, pótt sjaldnast komi fyrir tölfræðileg jákvæð marktækni. Einkavæddu fjármálafyrirtækin koma fyrir sem nokkurs konar útlagar í greiningunni. Pegar greiningar eru endurteknar án pessara útlaga (pað er að segja fjármálafyrirtækjanna tveggja) breytast niðurstöðurnar með peim hætti að einkavæðingin sýnir almennt ekki tölfræðilega jákvæða marktæka breytingu. Hins vegar sýnir rannsóknin fram á jákvæð áhrif á samanburðarhópinn, einkafyrirtækin. Einkavæddu fyrirtækin halda áfram að vera arðsöm og skilvirk, pó að fjölgun 
starfsmanna lækki suma mælikvarða á skilvirkni, og breytast almennt í jákvæða átt samkvæmt mælikvörðunum. Einkafyrirtækin bæta sig samkvæmt mörgum mælikvörðum pó að tveir mælikvarðar, skuldsetning og fjöldi starfsmanna, sýni að einkafyrirtækin færast marktækt í andstæða átt við einkavæddu fyrirtækin.

\section{Heimildir}

Barber, B. M. og Lyon, J. D. (1996). Detecting abnormal operating performance: The empirical power and specification of test statistics. Journal of Financial Economics, 41, 359-399.

Berglof, E. og Roland, G. (1998). Soft budget constraints and banking in transition economies. Journal of Comparative Economics, 26, 18-40.

Bishop, M. og Kay, J. (1988). Does privatization work? Lessons from the UK. London: Centre for Business Strategy, London Business School.

Boubakri, N. og Cosset, J. (1998). The financial and operating performance of newly privatised firms: Evidence from developing countries. Journal of Finance, 53, 1081-1110.

Boycko, M., Shleifer, A. og Vishny, R. W. (1994). Voucher privatization. Journal of Financial Economics, 35, 249-266.

Campbell, O. og Bhatia, A. (1998). Privatization in Africa, World Bank: Washington, DC.

Choi, S. D. og Megginson, W. (2010). Political economy of privatized economy. Sótt af http://papers.ssrn.com/sol3/papers.cfm?abstract_id=1518692

Choi, S. D. og Silanes, F. L. (2010). Political economy of privatized economy. Sótt af http://fma.org/NY/Papers/Pol_Econ_of_pn_econ_Florencio.pdf

Davis, J., Ossowski, R., Richardson, T. og Barnett, S. (2000). Fiscal and macroeconomic impact of privatisation. Washington, D.C.: International Monetary Fund.

Dewenter, K. og Malatesta, P.H. (2001). State-owned and privately-owned firms: An empirical analysis of profitability, leverage, and labour intensity. American Economic Review, 91, 32034.

D'Souza, J., Nash, R. og Megginson, W. L. (2000). Determinants of performance improvements in privatised firms: The role of restructuring and corporate governance Oklahoma: University of Oklahoma.

Frydman, R., Gray, C. W., Hessel, M. og Rapaczynski, A. (2000). The limits of discipline: Ownership and hard budget constrains in the transition economies. C.V. Starr Center for Applied Economics.

Gylfi Magnusson (2007). Markaður verður til: Saga íslenska hlutabréfamarkaðarins (skýrsla nr. R07:01). Reykjavík: Hagfræðistofunun Íslands, Háskóli Íslands.

Hansmann, H. og Krakkman, R. (2000). The end of history for corporate law (Yale Law School vinnupappír nr. 235; NYU vinnupappír nr. 013; Harvard Law School umræðupappír nr. 280; Yale SOM vinnupappír nr. ICF - 00-09). Sótt af http://ssrn.com/abstract=204528 or doi:10.2139/ssrn.204528

International Monetary Fund (2007). Iceland: 2007 Article IV Consultation - Staff Report. Sótt af http://www.imf.org/External/Pubs/FT/SCR/2007/cr07295.pdf 
Kikeri, S. og Nellis, J. (2002). Privatisation in competitive sectors: The record to date (World Bank Policy Research vinnupappír nr. 2860). Washington, D.C.: World Bank.

Kornai, J. (1998). Legal obligation non-compliance and soft budget constraint. The new palgrave dictionary of economics and law. London: Macmillan \& Co.

La Porta, R. og López-de-Silanes, F. (1999). Benefits of privatization - Evidence from Mexico. Quarterly Journal of Economics, 114, 1193-242.

Már Wolfgang Mixa og Pröstur Olaf Sigurjónsson (2010). Áfram á rauðu ljósi - fjármálahrunið á Íslandi og reynsla Norðurlandanna. Tímarit um viðskipti og efnahagsmál, 7(1), 21-40.

Martin, S. og Parker, D. (1997). The impact of privatisation. Ownership and corporate performance in the UK. London: Routledge.

Megginson, W. (2003). The economics of bank privatization. Sótt af http://siteresources.worldbank.org/INTFR/Resources/4754591107978088492/TheEconomicsofBankPrivatization.pdf

Megginson, W. og Choi, S.D. (2010). Political economy of privatized economy. Sótt af http://ssrn.com/abstract=1571973.

Megginson, W., Nash, R. C. og Randenborgh, M. (1994). The financial and operating performance of newly privatised firms: An international empirical analysis. Journal of Finance, 49, 403-452.

Megginson, W. og Netter, J. (2001). From the State to market: A survey of empirical studies on privatisation. Journal of Economic Literature, 39, 321-389.

OECD (2006). Economic survey of Iceland 2006. Sótt af http://www.oecd.org/document/32/0,2340,en_2649_34569_37216992_1_1_1_1,00.html

Rannsóknarnefnd Alpingis (2010). Aðdragandi og orsakir falls íslensku bankanna 2008 og tengdir atburðir. Sótt 2. maí 2011 af http://rna.althingi.is

Ríkisendurskoðun (2003). Einkavæðing helstu ríkisfyrirtækja árin 1998-2003. Sótt af http://www.rikisendurskodun.is/fileadmin/media/skyrslur/einkavaeding.pdf

Ríkisendurskoðun (2009). Upplýsingar um fjárframlög fyrri ára til stjórnmálastarfsemi. Sótt af http://rikisendurskodun.is/index.php?module=news\&action=show\&news_id=154\&languag $\mathrm{e}=\mathrm{is}$

Sheshinski, E. og Lopez-Calva, L. (1999). Privatization and its benefits: Theory and evidence (HIID umræðupappír nr. 698). Cambridge, MA.: Harvard University.

Pröstur Olaf Sigurjonsson (2010). Governance of risk and performance. Corporate Governance. The International Journal of Business in Society, 10, 33-46.

Vining, A. R. og Boardman, A. E. (1992). Ownership versus competition: Efficiency in public enterprise. Public Choice, 73, 205-239.

Willner, J. (2003). Privatization and public ownership in Finland (CESifo vinnupappír nr. 1012). Munich: CESinfo. 